\title{
ENVIRONMENTAL PERFORMANCE AND RESPONSIBLE CORPORATE GOVERNANCE: AN EMPIRICAL NOTE
}

\author{
Voicu D. Dragomir
}

\section{Introduction}

Incorporating eco-sustainability criteria into the corporate agenda means assigning the natural environment such attributes as power, legitimacy, urgency and proximity [10]. The complexity and interconnectedness of global ecosystems make it difficult for managers to determine specific impacts on these systems; but that is only an excuse for trivial sustainability reporting and dubious triple-bottom-line assessments. And it is the very relationship between accountability in the form of disclosure and 'shareholder value' that has kept the business-case controversy alive [15].

There is also a second thing of vital importance, which we dare say has never been empirically tested: the effect of managerial discretion on environmental performance. Since legitimacy is now universally considered a vital resource for the organization [8], it is natural to hypothesize that in the long run those who do not use the power in a responsible manner will tend to lose it. Donna Wood [36] proposes a hierarchical view of corporate social responsibility (CSR) principles, with legitimacy being the root principle, public responsibility the second principle, and managerial discretion the last. Thus, in her formulation, reactive firms are motivated only by legitimacy, responsive firms by legitimacy and public responsibility - i.e. the outcomes related to their primary areas of involvement with society - and interactive firms by all three principles. However, on environmental matters these layers of responsibility tend to blend together, hence rendering empirical investigation a daunting task.

If we think in terms of reductions in greenhouse gas emissions, it is a mystery what amount is owed to simple compliance with state regulation, and what proportion is exclusively an outcome of the managers' decisions as moral actors [5]. Moreover, some authors completely disregard the possibility of discovering anything other than the profound reluctance of business leaders to be held even remotely accountable for their actions [26]. Hence it can be hypothesized that environment-centered, rather than business-centered, enterprises are still rare birds.

The present contribution seeks to capture the relationship between greenhouse gas emissions and company financial performance. The data were extracted from corporate annual and sustainability reports of Europe's largest industrial groups over a period between 2004 and 2007. The study's hypotheses are collated from a literature review spanning almost a quarter of a century, and panel data analysis is conducted using a variety of econometric methods and model specifications. The results are mixed, with pollution levels in some cases decreasing with better financial performance, while in others being positively related to profitability. The results are not robust across industries, and to several model misspecifications. Owing to the uniqueness of the database in use and to the complexity of the econometric analysis, our findings are another proof of the controversy surrounding the relationship between firm financial and environmental performance.

\section{A literature Review: The Environmental Performance / Financial Performance Relationship}

Correlational analysis has produced some interesting results, even if we believe that the statistical issues associated with inflated Type I errors and assumption testing have not been 
properly addressed. Pava \& Krausz [27] suggested that there is almost no evidence that socially responsible firms perform worse than other firms; in fact, most of the evidence pointed to a stronger financial performance of responsible firms, but also to a disproportion in size compared to the control group. Preston \& O'Bannon [28] computed 270 correlations in both contemporaneous and lead-lag form for a date set covering an 11-year time period; they found support for the hypothesis that there is a positive association between social and financial performance in large US firms, especially for the case of financial performance influencing social responsiveness. On the same note, Waddock \& Graves [33] evaluated the linkage between financial and social performance, using CSR as both a dependent and independent variable; they found that social responsibility positively depends on financial performance, but, at the same time, good financial ratios are correlated with lagged social performance, possibly forming a virtuous circle. Griffin \& Mahon [16] corroborate these results by arguing that they found no firms in the high corporate social performance and low financial performance group.

A large number of studies have envisaged corporate environmental (and social) performance as an explanatory variable for such outcomes as stock valuation and market risk. In this respect, Konar \& Cohen [19] found that poor environmental performance has a significant negative effect on the intangible-asset value of publicly traded firms, while the effect of toxic emission levels tends to be both statistically and economically significant. The above evidence is supported also by Freedman \& Patten [12] who suggest that companies with worse pollution performance suffered more negative market reactions than firms with lower emissions; on the other hand, voluntary environmental disclosure appears to mitigate the negative impact of actual performance information, which is consistent with the findings of Murray et al. [23]. Finally, the evidence brought by Ziegler et al. [38] is somewhat neutral: the stock market rewards investment in clean sectors with a premium, while the environmental and social behavior of managers does not diminish the stock performance of the corporation. However, it should be noted that their results indicate that a stronger sustainable behavior does not have a positive effect either, such that no explicit incentives for socially desirable activities can be clearly identified.

The studies using accounting measures of profitability on the dependent variables' side can be separated into two groups: the former dealing with the broader issue of social performance, and the latter using the more restrictive indicators of environmental performance as explanatory variables. The inquiry of Lopez et al. [20] shows that the effect of CSR practices was negative in the short-term, but positive effects on profitability were noticed several years after the inclusion of a company in a sustainability index. Perhaps unexpectedly, a composite measure of corporate social performance (CSP) may exhibit no relationship with traditional accounting measures of profitability, but component dimensions, like the environmental performance, actually might [21]. And it is quite common for researchers nowadays to proceed to itemize each CSR aspect, i.e. the environment, consumers, human rights, in order to gain more control over the analytic process.

Among all CSR dimensions, environmental performance has always been a focal point of research, partly because sustainability is becoming more and more of a newspaper headline, and partly because pollution levels and ratings are more easily quantifiable and comparable than other social performance measures. When profitability is measured with regard to return-on-assets (ROA), Russo \& Fouts [29] suggest that "it pays to be green", and that this relationship strengthens as industry growth increases. Conversely, Balabanis et al. [2] found that environmental protection, while carrying a higher cost for the firm, is also a low profitability driver for subsequent periods. This result is consistent with the reported findings of Wagner et al. [34], which resonate with the traditionalists' predictions [14] on the uniformly negative relationship between environmental performance and economic performance. Supporting evidence seems to pile up, according to Telle [31] who produces evidence that the previously-reported positive effect of plant-level environmental performance on accounting performance (return on sales) tends to dissolve when unobserved plant characteristics are accounted for using a random effects model for panel data. Finally, 
Van der Laan et al. [32] actually say that, apparently, a good reputation for being concerned with the environment leads to real monetary losses. Consequently, it seems that attaining a positive reputation requires investments up to a point where marginal returns may eventually outweigh marginal costs, thus rendering the conclusion that "it pays to be green" premature.

The relationship between environmental (and social) performance and accounting figures is still controversial, but researchers have come to agree that the legitimizing nature of environmental disclosures is boldly expressed whenever sustainability efforts are presented in monetary terms [7]. Beyond mere disclosure there lies a whole world of uncertainty, and researchers have had to deal with it ever since the first inquiries into the problematic relationship between corporate sustainability and firm economics.

\section{Sample Selection and Variable Description}

\subsection{The Identification and Measurement Issue}

Applied researchers are sometimes forced to ignore the theoretical consequences of introducing a new concept (e.g. environmental performance); more often, they will be tempted to adopt a less rigorous, but more down-to-earth exploratory effort of pinning down all visible implications. Therefore, the most important design and methodology issue related to environmental (and social) performance is the real-life identification of the actual construct [17].

For the purpose of this paper, the issue of performance indicator (or content) validity was paramount. That is why we hand-collected raw emissions data from the corporate annual reports of the largest European industrial groups. These data, expressed in uniform units of measurement, are used without subsequent rankings or classifications, in order to be able to draw valid conclusions on the relationship between emission levels and financial performance. We caution the reader not to immediately extrapolate pollution levels to the more comprehensive concept of environmental performance; in our view, the very careful determination of our performance indicator is a major strength, but also a limitation of this particular research design.
In their sustainability reports, large business groups generally disclose consolidated amounts of greenhouse gas emissions for all their subsidiaries and range of activities. Data are self-reported by all facilities within the consolidation perimeter, based on estimates or on actual measurements, depending on the production process, and refer exclusively to the carbon footprint of the facility, and not that of the products themselves. Thus we may question the reliability of the disclosed figures, just as we sometimes doubt "the true and fair view" generated by the accounting department. Nevertheless, the European Union policy has been designed to address greenhouse gas emission measurement and reporting issues, as well as allowance trading.

Since the United Nations Framework Convention on Climate Change entered into force on 21 March 1994, the European Union launched a debate on the suitability and possible functioning of greenhouse gas emissions trading within the EU borders. The Kyoto Protocol and its binding targets for 37 industrialized countries and the European community for reducing greenhouse gas (GHG) emissions, was implemented in conjunction with the Sixth Community Environment Action Programme which provided for the establishment of a Community-wide emissions trading scheme by 2005 . The regulatory output - mainly Directive 2003/87/EC establishing a scheme for greenhouse gas emission allowance trading - was especially designed to ensure sound reporting and robust verification for the activities of the operators which fall under the national allocation plan. However, of greatest interest to our research is the discussion of how companies can fulfill a complete, consistent, transparent and accurate monitoring and reporting of greenhouse gas emissions, in accordance with the guidelines laid down in the Decision 2004/156/EC, as amended by Decision 2007/589/EC5.

In the aforementioned Decision, the European Commission puts forward six monitoring and reporting principles: completeness, consistency, transparency, trueness, cost effectiveness, and faithfulness, which resemble the International Accounting Standards Board's (IASB) Conceptual Framework, or the Global Reporting Initiative's (GRI) Sustainability Reporting Guidelines. Next, it describes the calculation and measurementbased methodologies for the determination of 
emissions, alongside a detailed monitoring plan to be prepared by the operator (company or plant management), and checked and approved by the competent authority. Specific $\mathrm{CO}_{2}$ emissions calculation formulae are also provided for combustion emissions (based on fuel consumption) and process emissions (based on material consumption). Finally, control and verification procedures require that the operators shall establish, document, implement and maintain effective data acquisition and handling activities for the monitoring and reporting of greenhouse gas emissions. Overall, the European Commission has created the regulatory framework for the provision of reliable data, produced by certified measurement systems employing transparent methodologies.

This brief overview of relevant Community regulation was intended to convince the reader that, even if the data are collected from corporate sustainability reports, we can be reasonably assured that the calculation of emissions is at least free from material misstatements. Moreover, all the companies in our sample have established EN/ISO 14001 environmental management systems aimed at achieving the organization's environmental policy defined by the top management. Consequently, we strongly believe that the collected data, although not perfectly free from bias or non-conformities, are the best available at the moment in terms of relevance and reliability.

\subsection{Sample Description}

Our balanced panel data consist of 77 European business groups, for which the performance indicators were extracted over a four-year period, between 2004 and 2007, with a total of 308 observations. The parent company of each group is listed on a European market, and included in the Dow Jones STOXX sector indices available for Europe. We used the index component lists as of the end of August 2008, for the following classifications according to the companies' primary source of revenue (sector codes are between brackets): Industrials (2000), Basic Materials (1000), Oil \& Gas (0500) and Healthcare (4500). These sectors are environmentally sensitive; we expected therefore a higher level of environmental performance disclosure from their constituents. Table 1 contains a list of all sample companies and the country of incorporation for the parent of the group.
The dependent variable (GGE) is an environmental performance measure, namely consolidated greenhouse gas emissions for a whole financial year. It is expressed in kilotons of $\mathrm{CO}_{2}$ equivalent, and it was extracted from annual corporate sustainability reports beginning with 2004. The application of this selection criterion revealed profound differences in the quality of environmental disclosure among higher polluting sectors (see Table 2): companies activating in the production of Basic Materials exhibit higher levels of sustainability disclosure compared to the Oil \& Gas and Healthcare sectors. However, maybe not surprisingly, Oil \& Gas producers are as large a polluter as cement or steel industry members. These discrepancies are food for thought, as the literature has not documented until now the Europe-wide propensity for corporate environmental disclosure, in the context of sector analysis. The sample is representative, firstly because it tracks the largest by market capitalization of the European quoted business groups, and secondly because it encompasses companies from 16 Western and Central European countries, of which U.K. companies occupy more than a quarter of the sample $(25.9 \%)$, followed by France $(12 \%)$ and Switzerland (11\%).

Another element of novelty is represented by the configuration of a binary variable capturing the quality of sustainability governance. All listed companies are required to compile a corporate governance statement for the reporting year, but some do disclose more on their practices related to sustainability. Our binary variable is an interaction term between the presence of a particular governance structure, and the level of assurance of any company's annual sustainability report. Firstly we collected data on the presence of such board-level or managerial structures dealing with environmental protection, or more generally with sustainable development issues; 63 of a total of 77 companies have some kind of responsibility governance structure in place (e.g. the Sustainable Development Committee, or the Director of Sustainable Affairs). Secondly, we checked whether each company's latest sustainability report had been subject to independent assurance [1], [9], [24]. We considered a report to have received assurance only if the auditors' opinion made clear comments on the environmental data, not just on the presentation 
Business Administration and Management

Tab. 1:

A List of the Companies Included in the Analyzed Sample, their Country of Incorporation and CSR Score (i.e. the responsible governance binary variable)

\begin{tabular}{|c|c|c|c|c|c|}
\hline Company & Country & CSR & Company & Country & CSR \\
\hline ABB & $\mathrm{CH}$ & 1 & $\mathrm{~K}+\mathrm{S}$ & $\mathrm{DE}$ & 0 \\
\hline Abertis & ES & 1 & Lafarge & FR & 1 \\
\hline Acciona & ES & 1 & LONMIN & GB & 1 \\
\hline ACS & ES & 1 & Metso & $\mathrm{FI}$ & 0 \\
\hline Aéroports de Paris & FR & 0 & MONDI & GB & 1 \\
\hline Air Liquide & FR & 1 & Norsk Hydro & NO & 1 \\
\hline AMEC & GB & 0 & Novartis & $\mathrm{CH}$ & 1 \\
\hline Anglo American & GB & 1 & Novo Nordisk & DK & 0 \\
\hline Arkema & FR & 0 & Novozymes & DK & 0 \\
\hline AstraZeneca & GB & 1 & OMV & AT & 1 \\
\hline Atlas Copco & SE & 0 & Outokumpu & $\mathrm{FI}$ & 1 \\
\hline BAE Systems & GB & 0 & Premier Oil & GB & 0 \\
\hline Balfour Beatty & GB & 1 & Repsol YPF & ES & 1 \\
\hline BASF & $\mathrm{DE}$ & 0 & Rhodia & FR & 1 \\
\hline Bayer & $\mathrm{DE}$ & 1 & Rio Tinto & GB & 1 \\
\hline BG Group & GB & 1 & Roche & $\mathrm{CH}$ & 1 \\
\hline BHP Billiton & GB & 1 & Royal Dutch Shell & GB & 0 \\
\hline $\mathrm{BP}$ & GB & 1 & Ruukki & $\mathrm{FI}$ & 0 \\
\hline Brisa & PT & 1 & Saint-Gobain & FR & 0 \\
\hline Cairn Energy & GB & 1 & Sanofi-Aventis & FR & 1 \\
\hline Ciba & $\mathrm{CH}$ & 0 & Scania & SE & 0 \\
\hline CIMPOR & $\mathrm{PT}$ & 0 & SKF & SE & 1 \\
\hline Clariant & $\mathrm{CH}$ & 0 & Smith \& Nephew & GB & 0 \\
\hline Cobham & GB & 0 & Smiths Group & GB & 0 \\
\hline $\mathrm{CRH}$ & IE & 1 & Solvay & $\mathrm{BE}$ & 0 \\
\hline DSM & NL & 1 & StatoilHydro & NO & 0 \\
\hline ENI & IT & 1 & Stora Enso & $\mathrm{FI}$ & 1 \\
\hline Eramet & FR & 0 & Syngenta & $\mathrm{CH}$ & 1 \\
\hline Gamesa & ES & 1 & Titan Cement & GR & 1 \\
\hline Georg Fischer & $\mathrm{CH}$ & 1 & TNT & $\mathrm{NL}$ & 1 \\
\hline Givaudan & $\mathrm{CH}$ & 0 & Travis Perkins & GB & 0 \\
\hline GlaxoSmithKline & GB & 1 & Umicore & $\mathrm{BE}$ & 0 \\
\hline Grifols & ES & 0 & UPM Kymmene & $\mathrm{FI}$ & 0 \\
\hline HeidelbergCement & $\mathrm{DE}$ & 0 & Vallourec & FR & 1 \\
\hline Holcim & $\mathrm{CH}$ & 0 & Volvo & SE & 0 \\
\hline Holmen & SE & 1 & Wärtsilä & $\mathrm{FI}$ & 0 \\
\hline Imerys & FR & 1 & Xstrata & GB & 1 \\
\hline Italcementi & IT & 1 & Yara & NO & 0 \\
\hline Johnson Matthey & GB & 0 & & & \\
\hline
\end{tabular}

Note. The CSR score is the interaction between the presence of a governance structure dealing specifically with sustainability and the opinion of the independent auditor concerning the reliability of the data in the environmental reports. 
Tab. 2: Sample Constituents per Sector

\begin{tabular}{l|c|c|c|c} 
Sector & $\begin{array}{c}\text { Index } \\
\text { constituents } \\
\text { per sector }\end{array}$ & $\begin{array}{c}\text { Sample } \\
\text { firms per } \\
\text { sector }\end{array}$ & $\begin{array}{c}\text { Percentage } \\
\text { of selected } \\
\text { companies } \\
\text { per sector }\end{array}$ & $\begin{array}{c}\text { Percentage } \\
\text { of final } \\
\text { sample }\end{array}$ \\
\hline Industrials & 120 & 23 & 19.16 & 29.80 \\
\hline Basic Materials & 47 & 36 & 76.59 & 46.76 \\
\hline Oil \& Gas & 40 & 9 & 22.50 & 11.68 \\
\hline Healthcare & 33 & 9 & 27.27 & 11.68 \\
\hline Total & $\mathbf{2 4 0}$ & $\mathbf{7 7}$ & - & $100 \%$ \\
\hline
\end{tabular}

Tab. 3: Financial Accounting Indicators, Grouped into Several Classes (Part 1)

\begin{tabular}{|c|c|c|}
\hline Class & Ratio & Formula \\
\hline \multirow[t]{3}{*}{$\begin{array}{l}\text { 1. Asset utilization } \\
\text { measurements }\end{array}$} & $\begin{array}{l}\text { Asset age }(A A) \text { : indicates the extent to which } \\
\text { a company has continued to replace its } \\
\text { existing assets with new ones on an ongoing } \\
\text { basis. A high value indicates a high proportion } \\
\text { of modernized property, plant and equipment } \\
\text { (PPE). }\end{array}$ & $\begin{array}{l}\text { Carrying value of PPE / } \\
\text { Original cost of PPE }\end{array}$ \\
\hline & $\begin{array}{l}\text { Investment turnover ratio (ITR): signals the } \\
\text { ability of a company to convert its debt and } \\
\text { equity into sales. A high ratio indicates a high } \\
\text { level of efficiency in creating sales. }\end{array}$ & $\begin{array}{l}\text { Sales / } \\
\text { (Shareholders' equity + } \\
\text { Long-term liabilities) }\end{array}$ \\
\hline & $\begin{array}{l}\text { Sales per person ratio (SPP): high degrees } \\
\text { of employee efficiency are bound to result in } \\
\text { strong profitability. }\end{array}$ & $\begin{array}{l}\text { Annualized revenue / } \\
\text { Full-time equivalents }\end{array}$ \\
\hline \multirow[t]{2}{*}{$\begin{array}{l}\text { 2. Operating } \\
\text { performance } \\
\text { measurements }\end{array}$} & $\begin{array}{l}\text { Operating income to sales ratio (OIS): reveals } \\
\text { the return from standard operations, excluding } \\
\text { the impact of extraordinary and discontinued } \\
\text { operations. }\end{array}$ & $\begin{array}{l}\text { Operating income / } \\
\text { Revenue }\end{array}$ \\
\hline & $\begin{array}{l}\text { Net income to operating income ratio (NOI): } \\
\text { quantifies the effect of financing and other } \\
\text { elements on the reported operating income. }\end{array}$ & $\begin{array}{l}\text { Net income from } \\
\text { continuing operations / } \\
\text { Operating income }\end{array}$ \\
\hline \multirow[t]{2}{*}{$\begin{array}{l}\text { 3. Cash flow } \\
\text { measurements }\end{array}$} & $\begin{array}{l}\text { Cash flow from operations (CFO): can be } \\
\text { used to determine the extent to which cash } \\
\text { flow differs from the reported level } \\
\text { of operating income. }\end{array}$ & $\begin{array}{l}\text { Cash flow from operating } \\
\text { activities / } \\
\text { Operating income }\end{array}$ \\
\hline & $\begin{array}{l}\text { Cash flow return on assets (CFR): is used to } \\
\text { calculate the amount of cash that a company } \\
\text { is generating in proportion to its asset level. }\end{array}$ & $\begin{array}{l}\text { Cash flow from operating } \\
\text { activities / } \\
\text { Total assets }\end{array}$ \\
\hline
\end{tabular}




\begin{tabular}{|c|c|c|c|}
\hline \multicolumn{2}{|c|}{ Class } & Ratio & Formula \\
\hline & \multirow[t]{3}{*}{$\begin{array}{l}\text { Liquidity } \\
\text { measurements }\end{array}$} & $\begin{array}{l}\text { Current ratio (CR): is used by lenders to } \\
\text { determine whether a company has sufficient } \\
\text { liquidities to pay its debt. }\end{array}$ & $\begin{array}{l}\text { Current assets / } \\
\text { Current liabilities }\end{array}$ \\
\hline & & $\begin{array}{l}\text { Cash ratio }(\mathrm{CSH}) \text { : uses only cash and } \\
\text { short-term marketable securities in the } \\
\text { numerator, so it is the best way to see what } \\
\text { proportion of liabilities can be paid immediately. }\end{array}$ & $\begin{array}{l}\text { Cash and short term } \\
\text { investments / } \\
\text { Current liabilities }\end{array}$ \\
\hline & & $\begin{array}{l}\text { Short-term to long-term debt (SLD): reveals } \\
\text { the proportion of total debt that is coming due } \\
\text { for payment in the near term. }\end{array}$ & $\begin{array}{l}\text { Total short-term debt / } \\
\text { Total debt }\end{array}$ \\
\hline & \multirow[t]{2}{*}{$\begin{array}{l}\text { Capital structure } \\
\text { measurements }\end{array}$} & $\begin{array}{l}\text { Debt to equity ratio (DTE): reveals the extent } \\
\text { to which company management is willing to } \\
\text { fund its operations with debt, rather than equity. }\end{array}$ & $\begin{array}{l}\text { Total debt / } \\
\text { Equity }\end{array}$ \\
\hline & & $\begin{array}{l}\text { Funded capital ratio (FCR): shows the } \\
\text { proportion of fixed assets that are being } \\
\text { funded by long-term funding, which is defined } \\
\text { as long-term debt and stockholders' equity. }\end{array}$ & $\begin{array}{l}\text { (Stockholders' equity + } \\
\text { Long-term debt) / } \\
\text { Non-current assets }\end{array}$ \\
\hline \multirow{3}{*}{\multicolumn{2}{|c|}{$\begin{array}{l}\text { 6. Return on investment } \\
\text { measurements }\end{array}$}} & $\begin{array}{l}\text { Return on assets employed (ROAE): } \\
\text { is considered critical for determining } \\
\text { a company's overall level of operating efficiency. } \\
\text { We use net income from continuing operations. }\end{array}$ & $\begin{array}{l}\text { Net profit / } \\
\text { Total assets }\end{array}$ \\
\hline & & $\begin{array}{l}\text { Operating return on equity (ROE): is used by } \\
\text { investors to determine the amount of return } \\
\text { they are receiving from their capital investment } \\
\text { in a company. }\end{array}$ & $\begin{array}{l}\text { Operating income / } \\
\text { Equity }\end{array}$ \\
\hline & & $\begin{array}{l}\text { Earnings per share (EPS): is the standard } \\
\text { used to compare the financial results } \\
\text { of publicly held companies. }\end{array}$ & $\begin{array}{l}\text { Net income / } \\
\text { Number of shares } \\
\text { outstanding }\end{array}$ \\
\hline
\end{tabular}


of the report or on the implementation of environmental management systems. Consequently, the interaction between the presence of sustainability governance structures and the presence of independent assurance resulted in an objective and original dichotomy coded CSR, awarding one point for socially responsible governance, found in 42 companies, and none for the remaining 35 firms (see Tab. 1 for the distribution of the binary score for the entire sample).

Company size is the most common control variable to be found in the literature [25]. In our study, it is operationalized through two indicators: consolidated total assets (TA), expressed in millions and converted to the Euro at year-end exchange rates; and number of full-time equivalent employees $(E M P)$ at the end of the fiscal year, as disclosed within the annual reports. It is expected that these two measures of company size in absolute terms to be highly correlated with pollution levels, in order to explain static inter-firm differences.

Another measure bound to capture the variation between companies is a five-year average of the industry return on assets (IROA), as suggested by Russo \& Fouts [29]. Following the guidelines offered by Reuters.com, we classified our four-sector companies into 28 industries, for which IROA was already present on the mentioned website. One disadvantage of this indicator is that it aggregates asset returns for companies on five continents, thus diminishing its relevance for the European territory.

To test the relationship between environmental performance and financial performance, we collected data for fifteen accounting performance measures (see Table 3 for a detailed presentation). We believe that this is to date the most comprehensive financial performance database in use for this type of study [16], mainly because we encompassed a range of performance measurement spanning six broad classes [6]. It is worth noting that companies' adoption of the International Financial Reporting Standards (IFRS) led to comparable data for 2004, for which listed European firms were required to issue 'in compliance' financial statements; thus, accounting data before 2004 was not suitable for our study, due to lack of comparability.

\section{Hypotheses, Methodology and Results}

\subsection{Sustainability Governance and Firm Performance}

The literature has not documented until now the effect of sustainability governance on actual pollution levels. We use our dichotomous variable $C S R$ to capture board involvement in sustainability issues, but only as far as a binary variable can go. Therefore, we do not expect high sensitivity to environmental and social challenges, but rather a bird's-eye view on the two groups that exhibit CSR involvement or CSR indifference. We will formulate our first two hypotheses as follows:

$H_{a}^{1}$ : Companies involved in CSR activities at board level will be smaller polluters than CSR indifferent firms.

$H_{2}$ : Sustainability governance has an impact on the enterprises' financial performance levels.

The results are displayed in Table 4. Naturally, we use classical parametric t-tests to assess the differences between the two groups. However, we do not rely fully on these tests, as several assumptions must be validated. Firstly, Levene's test indicates that the homogeneity of variance assumption is generally not violated, with the exception of three financial performance measures (OIS, SLD, and EPS). Even so, the parametric t-test includes Welch's correction for unequal variances, as a measure of precaution. Secondly, the normality assumption is violated for almost every variable. We use ShapiroWilk's statistic to test the null hypothesis that the two groups are extracted from normally distributed populations in the context of each performance measure. We strongly reject that null hypothesis, and consequently use nonparametric tests of differences between two independent means (Mann-Whitney) for our hypotheses.

Total assets (TA) and number of employees $(E M P)$ are significantly larger for CSR involved companies; also, it appears that CSR involvement leads to a lower capacity to convert corporate debt and equity into sales (ITR). On the other hand, sustainability governance appears to discriminate between corporate profitability levels, as operating income to sales (OIS) and earnings per share (EPS) are significantly higher for those companies which adopt 


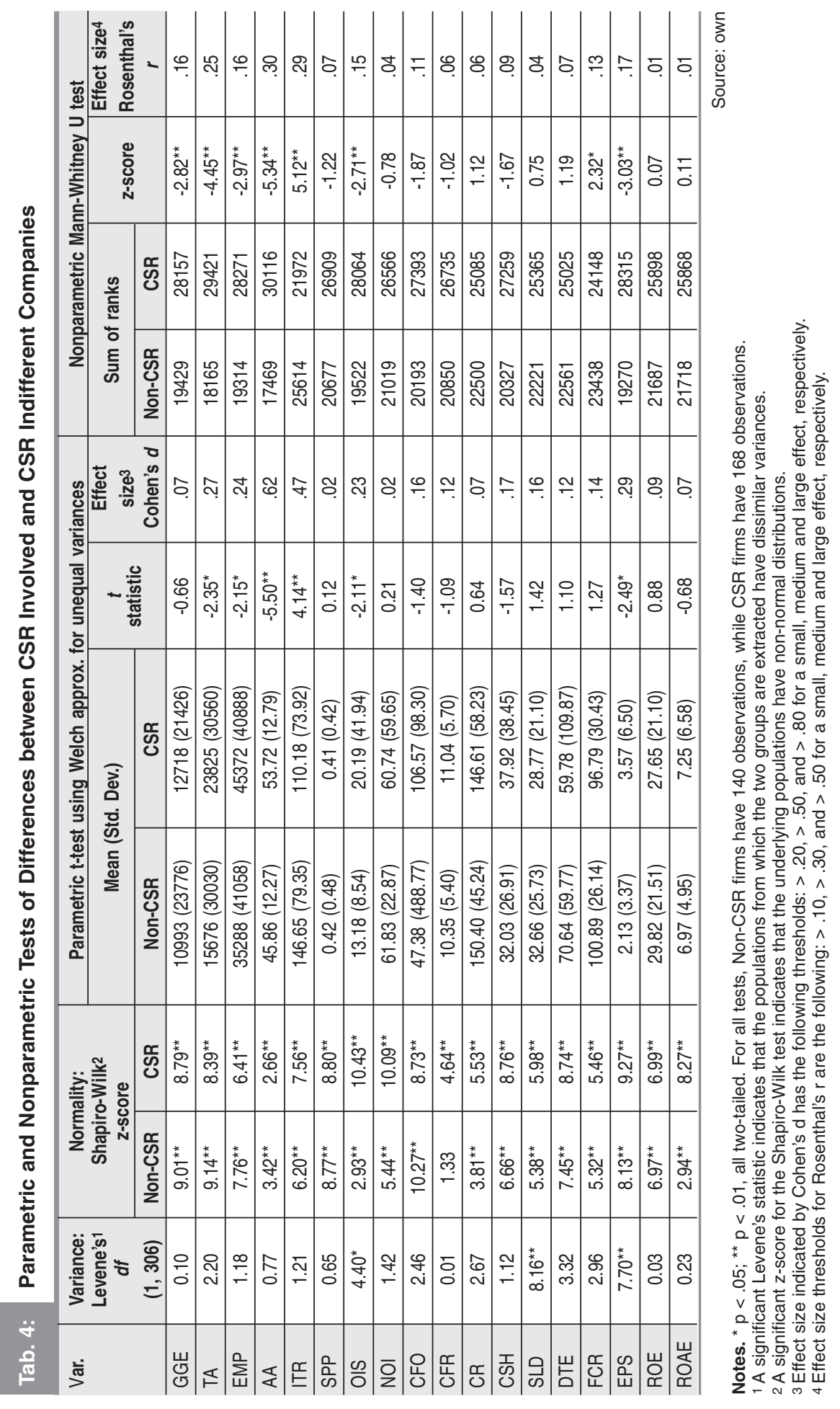


independently audited CSR policies. It must be noted that the statistical effects for the financial performance indicators remain within the 'small' interval. In that sense, parametric and nonparametric tests are consistent mainly because they all report statistical results of lesser practical importance, and thus not very conclusive.

However, the nonparametric tests capture two more points of divergence between our two groups. Firstly, CSR indifferent companies appear to have a higher proportion of fixed assets funded from long-term capital (FCR), but to a very small effect. And secondly, CSR involved enterprises are bigger polluters (GGE), thus rejecting hypothesis $H_{a}^{1}$, but to a small statistical effect. The parametric t-test does not capture this difference in means, which may be due to the extremely high positive skewness of pollution levels for our sample.

All in all, if we take the effect size as a definitive criterion, we can say little about the differences to be found between the two groups. The small to medium effect concerning asset age $(A A)$ may be due to the particularities of each sector, but the sample size does not permit us to investigate any further. Conversely, the higher levels of investment turnover (ITR) found to belong to CSR indifferent firms are not implicitly connected to bottom line profitability. But most importantly, sustainability governance appears to fail the challenge of increased pollution; alternatively, CSR policies may not be destined to address environmental issues, but to repair legitimacy through disclosure. Statistics will never provide a definitive answer to this dilemma, hence legitimacy will remain unobservable.

\subsection{Regression Analysis: Results and Discussion}

The panel structure gives us the unique opportunity of having "more informative data, more variability, less collinearity among variables, more degrees of freedom and more efficiency" [3]. Our formulation of an alternative hypothesis for regression analysis is:

$H_{a}^{3}$ : Greenhouse gas emission levels are significantly related to contemporaneous financial performance, after controlling for unobserved individual and sector characteristics.

The random-effects model is appropriate for our panel data structure [13]. In spite of a possible self-selection bias resulting from size or industry attributes, we can safely consider our sample to be randomly extracted from the population of large European companies. In this situation, it is natural to use subjectspecific parameters to represent the heterogeneity among subjects. Panel-data theorists [37] recommend using the random-effects model in studies where the time dimension is small ( $T=4$ in our case), because fewer degrees of freedom are necessary to account for the subject-specific parameters. This specification also has the advantage of accommodating group fixed effects, like industry or CSR dummies.

Thus, the estimation of the random-effects model assumes that the dependent variable is a normally distributed independent random variable, conditional on the error components. Since the distribution of the untransformed GGE was positively skewed (skewness $=2.64$, kurtosis = 9.50), we use the logarithmic transformation on GGE, which imposes to change the interpretation of regression coefficients from absolute to relative changes in the dependent variable. Visually inspecting the distribution of Log of GGE suggests normality, but the more formal Shapiro-Wilk test rejects the null hypothesis ( $\mathrm{W}=0.97, \mathrm{p}<.001)$; however, we must remember that tests such as the above tend to declare non-normality based on very small deviations in large samples [11].

Correlation analysis is a preliminary step in discussing the implications of multicollinearity in regression analysis. Table 5 displays the parametric (Pearson's $r$ ) and nonparametric (Spearman's $\rho$ ) matrix for the dependent and covariate variables. We use both types of correlation measures because we believe that in some cases the parametric assumption of Pearson's test may be violated. The results are qualitatively identical, with high correlations (greater than .60) between the untransformed GGE and firm size indicators, i.e. TA (total assets) and EMP (number of employees). On each side of the table, only five more significant correlations are above the .60 threshold, notably those between ROAE and three other variables: OIS, CFR, and EPS. Overall, it appears that $G G E$ is not significantly related to any variables except the firm size proxies, while the financial performance measures are largely independent of each other. Since TA and EMP are highly correlated $(r=.58, \rho=.81)$, we will use them alternatively in our model building. In 
崖|

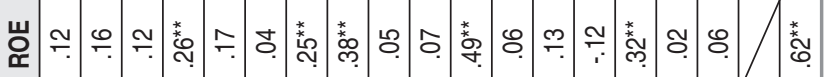

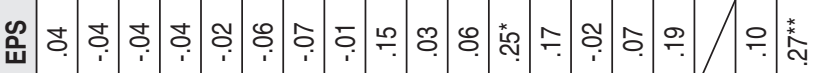

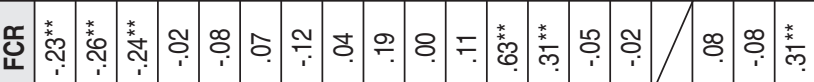

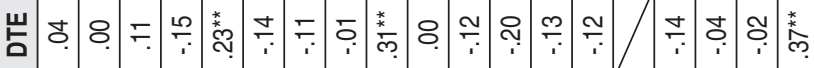

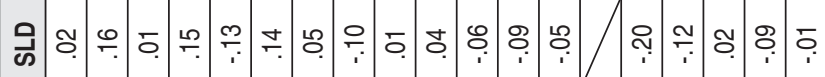

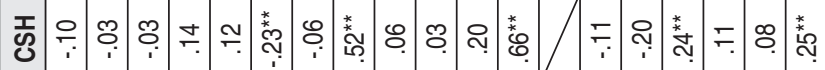

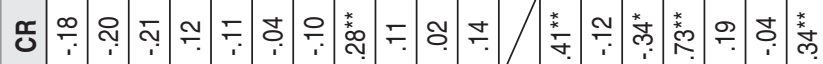

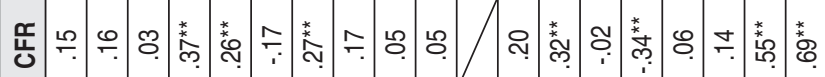

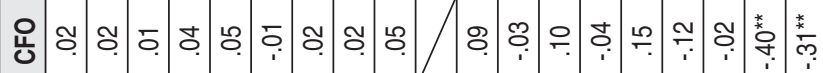

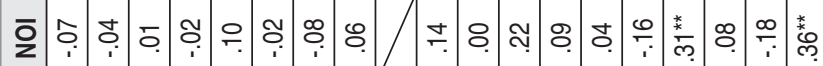
உ

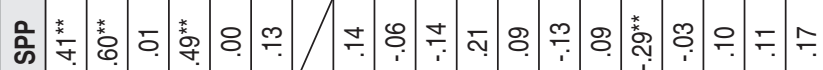

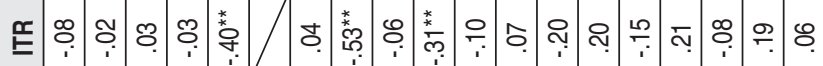

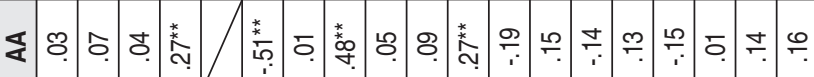

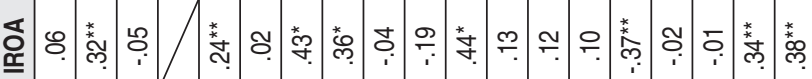

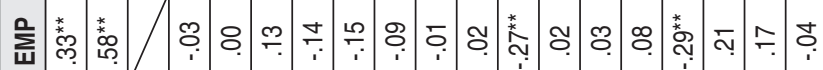

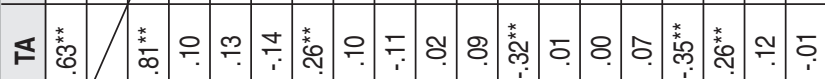

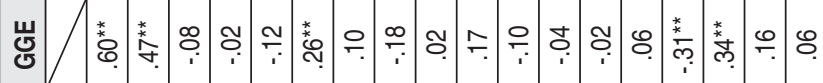


order to improve the predictive ability of the models by means of approaching normality in the firm size proxies, we use $\log$ of TA and $\log$ of EMP, which are also highly correlated with each other $(r=.78, \rho=.81)$.

The results of regression analysis will be discussed in the context of several model specifications. Table 6 shows the base model estimation with all 15 financial performance indicators as predictors, plus the CSR binary variable; industry fixed effects are included in the extended specification; finally, the addition of company size control variables serve to complete the model building process. The story behind the changes in explanatory power can be summarized as follows: the base model is better at explaining the variation within the entities ( $R^{2}$ within $\left.=.1854\right)$, but does a very unsatisfactory job at explaining the differences between companies ( $R^{2}$ between $=.0747$ ). As expected, the industry fixed effects improve explanatory power only for the differences between the units ( $R^{2}$ between $\left.=.4059\right)$. When taking into account the number of employees for each firm-year observation, we manage to better explain the variation within each company ( $R^{2}$ within = .3104), and also between the sample firms $\left(R^{2}\right.$ between $\left.=.6451\right)$. The alternative specification with total assets as a proxy for company size explains more of the variation within the units $\left(R^{2}\right.$ within $\left.=.3680\right)$, but less of the differences between companies ( $R^{2}$ between $=.6118$ ).

A very interesting result, which is consistent across all specifications, is that return on equity $(R O E)$ is positively and significantly related to increases in pollution levels. On the other hand, responsible governance (CSR) appears to make no difference in pollution control. When including the industry fixed effects, the base category is set to the Industrials sector, which is not significantly different from Healthcare in terms of greenhouse gas emissions. However, companies belonging to the Basic Materials and Oil \& Gas industries have visible highpolluter profiles, but emission levels seem to be significantly lower for firms belonging to industries with a higher 5-year average profitability $(I R O A)$. It is somewhat puzzling to notice that sales per person (SPP) is positively related to emission levels when the number of employees is used as a control variable, but negatively related when $\log$ of $T A$ is used as a proxy for firm size. Capital structure measures (FCE and DTE) are both negatively linked to pollution levels; in the case of debt to equity ratio (DTE), emissions appear to decrease for a positive change in the proportion of debt over equity; conversely, pollution levels are increasing for a lower proportion of fixed assets funded through long-term capital. Finally, satisfactory sales efficiency (ITR) and return from operations (OIS) are linked to significant decreases in pollution levels.

For the base model specification, the results are not robust across industries (see Table 7). The most important remark is that the sign of some significant coefficients is not consistent across models; notice the incompatibilities for the ROE and ROAE predictors. The signs are consistent, but the coefficient standard errors too high for variables such as asset age $(A A)$, investment turnover ratio (ITR), operating income per sales (OIS), net income to operating income ratio (NOI) and funded capital ratio $(F C R)$. The evidence is overwhelmingly though in favor of a negative relationship between financial performance and emission levels. Only the 23 companies belonging to the Industrials group seem to increase their sales per person $(S P P)$ and earnings per share (EPS) while also becoming bigger polluters. Surprisingly, responsible governance (CSR) is also related to higher pollution levels for firms activating in the Oil \& Gas sector. The predictive ability of the four industry-tailored models is also extremely inconsistent, with two of them explaining almost $100 \%$ of variation between entities (Oil \& Gas and Healthcare), and the Industrials model explaining almost nil. Overall, it appears that industry-specific heterogeneity is a major obstacle in obtaining reliable estimates of model coefficients.

We used the Huber [18] / White [35] / sandwich estimator implemented in the Stata software [30] to compute robust variances, in order to give accurate assessments of the sample-tosample variability of the parameter estimates even when the model is misspecified. The results presented in Table 8, under the Heteroscedasticity robust models heading, are consistent with the previous findings, in that industry dummies, industry profitability and size proxies are all highly significant. However, sales per person $(S P P)$ has an inconsistent sign when alternate company size measures are used, and only the operating income to sales ratio 
Business Administration and Management

\begin{tabular}{|c|c|c|c|c|}
\hline Tab. 6: & $\begin{array}{l}\text { a Regression } \\
\text { t variable: nat }\end{array}$ & $\begin{array}{l}\text { lysis in Conter } \\
\text { I logarithm of }\end{array}$ & $\begin{array}{l}\text { raneous Setting } \\
\text { enhouse gas emi }\end{array}$ & sions) \\
\hline \multirow[t]{2}{*}{ Vars } & \multirow{2}{*}{$\begin{array}{l}\text { Base model } \\
\text { with CSR fixed } \\
\text { effects }\end{array}$} & \multirow{2}{*}{$\begin{array}{l}\text { With industry } \\
\text { fixed effects }\end{array}$} & \multicolumn{2}{|c|}{ With company size control variables } \\
\hline & & & No. of employees & Total assets \\
\hline Intercept & $7.013(<.01)^{\star \star}$ & $6.57(<.001)^{\star \star}$ & $0.4666(.557)$ & $1.8556(.005)^{\star \star}$ \\
\hline CSR dummy & $0.6356(.164)$ & $0.4377(.266)$ & $0.2070(.486)$ & $0.1770(.562)$ \\
\hline BM dummy & & $2.71(<.001)^{\star \star}$ & $2.71(<.001)^{\star \star}$ & $2.52(<.001)^{\star \star}$ \\
\hline OG dummy & & $4.84(<.001)^{\star \star}$ & $4.53(<.001)^{\star \star}$ & $4.06(<.001)^{\star *}$ \\
\hline HC dummy & & $1.31(.076)$ & $0.7242(.196)$ & $0.5074(.380)$ \\
\hline IROA & & $-0.2748(.003)^{\star *}$ & $-0.1985(.005)^{\star *}$ & $-0.2046(.005)^{\star *}$ \\
\hline Log of EMP & & & $0.6254(<.01)^{\star \star}$ & \\
\hline Log of TA & & & & $0.5728(<.01)^{\star \star}$ \\
\hline AA & $0.0033(.352)$ & $0.0041(.236)$ & $-0.0001(.958)$ & $-00023(.457)$ \\
\hline ITR & $-0.0008(.105)$ & $-0.0006(.159)$ & $-0.0016(<.01)^{\star \star}$ & $-0.0002(.651)$ \\
\hline SPP & $0.2076(.040)^{*}$ & $0.1600(.109)$ & $0.2342(.013)^{*}$ & $-0.2511(.012)^{*}$ \\
\hline OIS & $-0.0007(.444)$ & $-0.0009(.358)$ & $-0.0015(.092)$ & $-0.0031(.001)^{\star *}$ \\
\hline $\mathrm{NOI}$ & $-0.0002(.432)$ & $-0.0002(.439)$ & $-0.0002(.367)$ & $-0.0002(.384)$ \\
\hline CFO & $-0.0001(.950)$ & $-0.0001(.882)$ & $0.0001(.698)$ & $-0.0001(.819)$ \\
\hline CFR & $0.0011(.780)$ & $0.0013(.728)$ & $0.0005(.880)$ & $0.0041(.249)$ \\
\hline CR & $-0.0015(.021)^{\star}$ & $-0.0016(.011)^{\star}$ & $-0.0010(.104)$ & $0.0001(.844)$ \\
\hline $\mathrm{CSH}$ & $0.0010(.284)$ & $0.0011(.234)$ & $0.0011(.192)$ & $0.0007(.368)$ \\
\hline SLD & $-0.0002(.704)$ & $-0.0003(.650)$ & $0.0008(.266)$ & $0.0004(.535)$ \\
\hline DTE & $0.0002(.525)$ & $0.0002(.353)$ & $-0.0002(.443)$ & $-0.0007(.011)^{\star}$ \\
\hline FCR & $0.0001(.859)$ & $0.0004(.618)$ & $-0.0010(.227)$ & $-0.0024(.012)^{\star}$ \\
\hline EPS & $0.0026(.643)$ & $0.0019(.722)$ & $0.0014(.782)$ & $-0.0069(.170)$ \\
\hline ROE & $0.0046(<.01)^{\star *}$ & $0.0047(<.001)^{\star \star}$ & $0.0047(<.01)^{\star *}$ & $0.0049(<.01)^{\star \star}$ \\
\hline ROAE & $-0.0002(.734)$ & $-0.0014(.841)$ & $0.0018(.782)$ & $0.0074(.246)$ \\
\hline Wald $\chi^{2}$ & $\begin{array}{l}50.66^{\star *} \\
(d f=16)\end{array}$ & $\begin{array}{l}103.87^{\star *} \\
(d f=20)\end{array}$ & $\begin{array}{l}241.48^{\star *} \\
(d f=21)\end{array}$ & $\begin{array}{l}249.78^{\star *} \\
(d f=21)\end{array}$ \\
\hline$R^{2}$ withint & .1854 & .1870 & .3104 & .3680 \\
\hline$R^{2}$ betweentt & .0746 & .4059 & .6451 & .6118 \\
\hline$R^{2}$ overalltt† & .0747 & .4049 & .6433 & .6105 \\
\hline
\end{tabular}

Notes. ${ }^{*} p<.05 ;{ }^{* *} p<.01$.

We specified random-effects models using the feasible GLS estimator.

For each model, we present the unstandardized coefficients, with their p-values between parentheses.

$\dagger R^{2}$ within indicates explained variation of emissions during the four-year period, for each company.

t† $\mathrm{R}^{2}$ between indicates explained variation between companies.

t†t $\mathrm{R}^{2}$ overall is defined as the squared correlation between observed and predicted values. 


\section{Ekonomika a management}

\begin{tabular}{|c|c|c|c|c|}
\hline Tab. 7: & $\begin{array}{l}\text { on Results for } \\
\text { ependent varia }\end{array}$ & $\begin{array}{l}\text { Base Model wi } \\
\text { : natural logarit }\end{array}$ & $\begin{array}{l}\text { CSR Fixed Effect } \\
\text { of Greenhouse }\end{array}$ & $\begin{array}{l}\text { Grouped by } \\
\text { as emissions) }\end{array}$ \\
\hline Vars & $\begin{array}{c}\text { Industrials } \\
(23 \text { companies) }\end{array}$ & $\begin{array}{l}\text { Basic materials } \\
\text { (36 companies) }\end{array}$ & $\begin{array}{c}\text { Oil \& Gas } \\
\text { (9 companies) }\end{array}$ & $\begin{array}{c}\text { Healthcare } \\
\text { (9 companies) }\end{array}$ \\
\hline Intercept & $4.9924(<.001)^{\star \star}$ & $8.9755(<.001)^{\star *}$ & $22.77(<.001)^{\star *}$ & $24.36(<.001)^{\star \star}$ \\
\hline CSR dummy & $0.2241(.750)$ & $0.1073(.852)$ & $0.8684(.002)^{\star *}$ & $0.3259(.680)$ \\
\hline AA & $0.0052(.542)$ & $-0.0049(.350)$ & $-0.1373(<.001)^{\star *}$ & $-0.0519(.008)^{\star \star}$ \\
\hline ITR & $-0.0006(.460)$ & $-0.0020(.004)^{\star \star}$ & $-0.0021(.776)$ & $-0.0487(<.01)^{\star *}$ \\
\hline SPP & $2.5388(.006)^{\star \star}$ & $0.0128(.948)$ & $0.2553(.429)$ & $1.3962(.877)$ \\
\hline OIS & $-0.0013(.931)$ & $-0.0027(.567)$ & $-0.0490(<.001)^{\star *}$ & $-0.1649(.021)^{*}$ \\
\hline $\mathrm{NOI}$ & $0.0011(.524)$ & $0.0001(.801)$ & $-0.0833(<.001)^{\star *}$ & $-0.1070(<.01)^{\star \star}$ \\
\hline CFO & $0.003(.458)$ & $0.0001(.682)$ & $0.0046(.066)$ & $0.0010(.832)$ \\
\hline CFR & $0.0191(.065)$ & $-0.0038(.404)$ & $-0.1218(.039)^{*}$ & $0.0561(.515)$ \\
\hline $\mathrm{CR}$ & $-0.0045(.060)$ & $-0.0001(.901)$ & $0.0011(.902)$ & $-0.0020(.857)$ \\
\hline $\mathrm{CSH}$ & $0.0059(.023)$ & $-0.0001(.931)$ & $-0.0057(.475)$ & $0.0070(.572)$ \\
\hline SLD & $-0.0007(.718)$ & $-0.0005(.675)$ & $0.0053(.341)$ & $-0.0089(.346)$ \\
\hline DTE & $0.0004(.458)$ & $-0.0012(.025)^{*}$ & $-0.0156(.065)$ & $-0.0062(.302)$ \\
\hline FCR & $0.0011(.637)$ & $-0.0036(.007)^{\star \star}$ & $-0.0215(.336)$ & $-0.0520(.008)^{\star \star}$ \\
\hline EPS & $0.0265(.044)^{*}$ & $-0.0025(.637)$ & $0.0589(.684)$ & $0.1825(.512)$ \\
\hline ROE & $0.0139(.003)^{\star \star}$ & $0.0073(<.001)^{\star *}$ & $-0.0603(<.001)^{\star *}$ & $-0.0128(.640)$ \\
\hline ROAE & $-0.0706(.014)^{*}$ & $0.0060(.384)$ & $0.5425(<.001)^{\star *}$ & $0.5017(.003)^{\star *}$ \\
\hline $\begin{array}{l}\text { Wald } \chi^{2} \\
(d f=16)\end{array}$ & $61.44^{* *}$ & $99.49^{*}$ & $757.46^{\star *}$ & $121.89^{* *}$ \\
\hline$R^{2}$ within $†$ & .5511 & .5317 & .0114 & .0471 \\
\hline$R^{2}$ between $\dagger \dagger$ & .0000 & .3556 & .9948 & .9526 \\
\hline$R^{2}$ overall††† & .0014 & .3228 & .9755 & .8561 \\
\hline No. Obs. & 92 & 144 & 36 & 36 \\
\hline
\end{tabular}

Notes. ${ }^{*} p<.05 ;{ }^{* *} p<.01$.

Source: own

We specified random-effects models using the feasible GLS estimator.

For each model, we present the unstandardized coefficients, with their p-values between parentheses. 


\section{Business Administration and Management}

\begin{tabular}{|c|c|c|c|c|}
\hline Tab. 8: & $\begin{array}{l}\text { Regression Resu } \\
\text { nt variable: natur }\end{array}$ & $\begin{array}{l}\text { for the Models } \\
\text { garithm of Gre }\end{array}$ & $\begin{array}{l}\text { ith Company Size } \\
\text { nouse gas emissio }\end{array}$ & $\begin{array}{l}\text { Control Variable } \\
\text { is) }\end{array}$ \\
\hline \multirow[t]{2}{*}{ Vars } & \multicolumn{2}{|c|}{ Heteroscedasticity robust models } & \multicolumn{2}{|c|}{ Autocorrelated residuals models } \\
\hline & No. of employees & Total assets & No. of employees & Total assets \\
\hline Intercept & $0.4666(.606)$ & $1.8556(.010)^{*}$ & $-2.2984(.004)^{\star *}$ & $-0.8041(.270)$ \\
\hline CSR dummy & $0.2070(.483)$ & $0.1770(.555)$ & $0.1017(.600)$ & $0.0482(.808)$ \\
\hline BM dummy & $2.711(<.001)^{\star \star}$ & $2.5242(<.01)^{\star \star}$ & $2.7393(<.01)^{\star \star}$ & $2.4766(<.01)^{\star \star}$ \\
\hline OG dummy & $4.535(<.001)^{\star *}$ & $4.0617(<.01)^{\star \star}$ & $4.4282(<.01)^{\star *}$ & $3.7637(<.01)^{\star *}$ \\
\hline HC dummy & $0.7242(.108)$ & $0.5074(.316)$ & $0.4733(.196)$ & $0.1116(.768)$ \\
\hline IROA & $-0.1985(<.01)^{* *}$ & $-0.2046(.001)^{\star *}$ & $-0.1742(<.01)^{* *}$ & $-0.1775(<.01)^{\star *}$ \\
\hline Log of EMP & $0.6254(<.01)^{\star \star}$ & & $0.8813(<.01)^{\star \star}$ & \\
\hline Log of TA & & $0.5728(<.01)^{\star \star}$ & & $0.8587(<.01)^{\star *}$ \\
\hline AA & $-0.0001(.961)$ & $-0.0023(.502)$ & $0.0012(.794)$ & $-0.0031(.507)$ \\
\hline ITR & $-0.0016(.033)^{*}$ & $-0.0002(.743)$ & $-0.0023(.001)^{\star *}$ & $-0.0001(.922)$ \\
\hline SPP & $0.2342(.028)^{\star}$ & $-0.2511(0.019)^{*}$ & $0.3181(.030)^{*}$ & $-0.4495(.005)^{\star \star}$ \\
\hline OIS & $-0.0015(.083)$ & $-0.0031(.003)^{\star \star}$ & $-0.0024(.081)$ & $-0.0051(<.001)^{\star *}$ \\
\hline $\mathrm{NOI}$ & $-0.0002(.693)$ & $-0.0002(.705)$ & $-0.0001(.767)$ & $-0.0001(.780)$ \\
\hline CFO & $0.0001(.473)$ & $0.0001(.716)$ & $0.0001(.823)$ & $-0.0001(.932)$ \\
\hline CFR & $0.0001(.909)$ & $0.0041(.419)$ & $0.0023(.681)$ & $0.0075(.189)$ \\
\hline $\mathrm{CR}$ & $-0.0010(.096)$ & $0.0012(.850)$ & $-0.0006(.514)$ & $0.0012(.201)$ \\
\hline $\mathrm{CSH}$ & $0.0011(.169)$ & $0.0007(.391)$ & $0.0006(.642)$ & $-0.0001(.926)$ \\
\hline SLD & $0.0008(.279)$ & $0.0004(.593)$ & $0.0014(.177)$ & $0.0010(.358)$ \\
\hline DTE & $-0.0002(.650)$ & $-0.0007(.112)$ & $0.0002(.669)$ & $-0.0005(.278)$ \\
\hline FCR & $-0.0010(.296)$ & $-0.0024(.033)^{*}$ & $-0.0011(.437)$ & $-0.0032(.028)^{*}$ \\
\hline EPS & $0.0014(.787)$ & $-0.0069(.270)$ & $-0.0036(.642)$ & $-0.0152(.057)$ \\
\hline ROE & $0.0047(.078)$ & $0.0049(.068)$ & $0.0045(.008)^{\star *}$ & $0.0051(.003)^{\star \star}$ \\
\hline ROAE & $0.0018(.813)$ & $0.0074(.365)$ & $0.0095(.338)$ & $0.0214(.035)^{*}$ \\
\hline $\begin{array}{l}\text { Wald } \chi^{2} \\
(d f=22)\end{array}$ & $4064.20^{* *}$ & $3632.87^{* *}$ & $437.42^{* *}$ & $414.14^{* *}$ \\
\hline$R^{2}$ withint & .3104 & .3680 & .2813 & .3332 \\
\hline$R^{2}$ betweent + & .6451 & .6118 & .6929 & .6722 \\
\hline$R^{2}$ overallttt & .6433 & .6105 & .6901 & .6694 \\
\hline $\mathrm{rho}_{\mathrm{AR}(1)}$ & & & .3088 & .3215 \\
\hline
\end{tabular}

Notes. ${ }^{*} \mathrm{p}<.05 ;{ }^{* *} \mathrm{p}<.01$.

Source: own

We specified random-effects models using the GLS estimator.

For each model, we present the unstandardized coefficients, with their p-values between parentheses.

$\mathrm{rho}_{\mathrm{AR}(1)}$ is the estimated first-order autocorrelation coefficient, which is significantly different from $0 ; \mathrm{F}(1,76)=22.07$ 
(OIS) seems to be negatively related to increasing pollution levels. Otherwise, financial performance appears to be largely immune or indifferent to greenhouse gas emission levels, when the reported standard errors are robust to some kinds of misspecification.

For the same models as above (see Table 8), we fitted the cross-sectional time-series regression models when the disturbance term is first-order autoregressive [4], which is appropriate since the random-effects model can accommodate covariates that are constant over time. Again, return on equity $(R O E)$ is positively related to pollution intensity, while operating efficiency and investment turnover are negatively correlated to levels of greenhouse gas emissions. These specifications are better than the heteroscedasticity robust models in terms of overall predictive ability; we notice a $5 \%$ increase in overall $R^{2}$ for models using the size proxies alternatively. The autoregressive models are able to capture more of the variation between the entities, and less of the particularities of each period within the performance of individual companies.

\section{Limitations and Conclusions}

In the following paragraphs we survey the limitations of our study. The panel data is spanning a period between 2004 and 2007; hence, this rendered a possible time series analysis irrelevant. Moreover, period fixed effects specific to an event study were also disregarded due to the impossibility to clearly define the particularities of emission levels of one year over another. In this sense, there appears to be no systematic patterns over our period of interest in the quantities of carbon equivalent emissions. As a clear-cut limitation of our study, we should mention the lack of more developed dynamic models; this difficulty would be easily surpassed in a few years' time, when more comprehensive data is to accumulate.

The companies included in the sample are representative of their industries, but also of their country of origin; they are large contributors to national GDP, as well as important tax payers and employers. However, country differences are likely to become unobservable in this type of study, and for this sample of 77 entities it does not appear possible to trace the company's environmental performance to the incorporation country's governmental involvement in eco-sustainability.

There is always the question of data reliability: these multinational groups operate on five continents. We do not have one hundred percent certainty that the collection methods are consistent across production sites, that the final amounts fairly present a consolidated view of the polluter's profile, or that the assurance statements are written in good faith. Since all the information is selfreported, the credibility of our empirical research goes as far as the quality of the data extracted from corporate reports.

The main limitation of the present study is the inclusion of only the greenhouse gas emissions as the indicator of environmental performance. Economic impacts on the natural environment cannot be limited to carbon dioxide emissions, which are only a part of the total share of responsibility companies have towards protecting the earth. One could argue that waste management, toxic releases, noise and odor, water withdrawal and discharges, as well as the complex impact on biodiversity should also be used as environmental performance indicators. The present paper has presented empirical evidence on greenhouse gas emissions and their relationship to financial performance mainly due to the availability of panel data for this indicator. Even so, the sample could suffer of selection bias, because only companies with data for four consecutive years were included in the econometric analysis. Nevertheless, future studies should also analyze relevant data from other areas of environmental impact, such as effluents, waste, water, energy, materials, biodiversity or eco-efficiency.

To briefly summarize our contribution, it is necessary to highlight the relevance of this new dataset, containing aggregated greenhouse gas emission figures, as well as IFRS-compliant financial performance indicators, in a complex panel design focused on EU enterprises. We conducted several types of analyses, tailored to capture the sign and strength of the relationship between environmental and financial performance. We also introduced an innovative measure of responsible governance, as an interaction term between board-level innovations and the level of independent assurance. Our results are mixed, largely dependent on different model specifications and the several procedures to obtain robust 
standard errors. As expected, there is no definitive conclusion on the aforementioned relationship. Responsible governance seems to have an insignificant contribution to real sustainability performance, as well as to the economic welfare of the firm. Overall, we support McWilliams \& Siegel's [22] contention that CSR attributes here including emission reduction efforts - will have higher costs, but also higher revenues, resulting in a neutral relationship between CSR activity and firm financial performance.

This work was cofinanced from the European Social Fund through the Sectoral Operational Programme Human Resources Development 2007-2013, project number POSDRU/1.5/S/59184, "Performance and excellence in postdoctoral research in Romanian economics science domain".

\section{References}

[1] ADAMS, C. A. The ethical, social and environmental reporting performance portrayal gap. Accounting, Auditing \& Accountability Journal. 2004, Vol. 17, Iss. 5, pp. 731-757. ISSN 0951-3574.

[2] BALABANIS, G., PHILLIPS, H. C., LYALL, J. Corporate social responsibility and economic performance in the top British companies: are they linked? European Business Review. 1998, Vol. 98, Iss. 1, pp. 25-44. ISSN 0955-534X.

[3] BALTAGI, B. H. Econometric Analysis of Panel Data. 4th ed. Chichester: John Wiley and Sons Ltd., 2008. ISBN 978-0-262-23219-7.

[4] BALTAGI, B. H., WU, P. X. Unequally Spaced Panel Data Regressions With $\operatorname{Ar}(1)$ Disturbances. Econometric Theory. 1999, Vol. 15, Iss. 6, pp. 814-823. ISSN 0266-4666.

[5] BENN, S., DUNPHY, D. New forms of governance. Changing relationships between corporates, government and community. In BENN S., DUNPHY, D. (Eds.). Corporate governance and sustainability. Challenges for theory and practice. London: Routledge. 2007. pp. 9-35. ISBN 978-0415380621. [6] BRAGG, S. M. Business Ratios and Formulas. A Comprehensive Guide. Hoboken (NJ): John Wiley and Sons, 2007. ISBN 978-0-470-05517-5. [7] CHO, C. H., PATTEN, D. M. The role of environmental disclosures as tools of legitimacy: A research note. Accounting, Organizations and Society. 2007, Vol. 32, Iss. 7-8. pp. 639-647. ISSN 0361-3682.

[8] DEEGAN, C. The legitimising effect of social and environmental disclosures - a theoretical foundations. Accounting, Auditing \& Accountability
Journal. 2002, Vol. 15, Iss. 3, pp. 282-311. ISSN 0951-3574.

[9] DEEGAN, C., COOPER, B. J., SHELLY, M. An investigation of TBL report assurance statements: UK and European evidence. Managerial Auditing Journal. 2006, Vol. 21, Iss. 4, pp. 329-371. ISSN 0268-6902.

[10] DRISCOLL, C., STARIK, M. The Primordial Stakeholder: Advancing the Conceptual Consideration of Stakeholder Status for the Natural Environment. Journal of Business Ethics. 2004, Vol. 49, Iss. 1, pp. 55-73. ISSN 0167-4544.

[11] FIELD, A. Discovering statistics using SPSS. 2nd ed. London: Sage, 2005. ISBN 978-0761944522. [12] FREEDMAN, M., PATTEN, D. M. Evidence on the pernicious effect of financial report environmental disclosure. Accounting Forum. 2004, Vol. 28, Iss. 1, pp. 27-41. ISSN 1467-6303.

[13] FREES, E. W. Longitudinal and Panel Data. Analysis and applications in the social sciences. Cambridge (UK): Cambridge University Press, 2004. ISBN 978-0-521-53538-0.

[14] FRIEDMAN, M. The social responsibility of business is to increase its profits. New York Times Magazine. Sept. 13, 1970. Available also on: <http://www.colorado.edu/studentgroups/libertaria ns/issues/friedman-soc-resp-business.html>.

[15] GRAY, R. Social, environmental and sustainability reporting and organisational value creation. Whose value? Whose creation? Accounting, Auditing \& Accountability Journal. 2006, Vol. 19, Iss. 6, pp. 793-819. ISSN 0951-3574.

[16] GRIFFIN, J. J., MAHON, J. F. The corporate social performance and corporate financial performance debate. Business and Society. 1997, Vol. 36, Iss. 1, pp. 5-31. ISSN 1467-8594.

[17] HARRISON, J. S., FREEMAN, R. E. Stakeholders, Social Responsibility, and Performance: Empirical Evidence and Theoretical Perspectives. Academy of Management Review. 1999, Vol. 42, Iss. 5, pp. 479-485. ISSN 0363-7425.

[18] HUBER, P. J. The behavior of maximum likelihood estimates under nonstandard conditions. Proceedings of the Fifth Berkeley Symposium on Mathematical Statistics and Probability. Vol. 1. Berkeley: University of California Press, 1967, pp. 221-233. Available also on: <http://projecteu clid.org/euclid.bsmsp/1200512988>.

[19] KONAR, S., COHEN, M. A. Does the Market Value Environmental Performance? The Review of Economics and Statistics. 2001, Vol. 83, Iss. 2, pp. 281-289. ISSN 0034-6535. 
[20] LOPEZ, M. V., GARCIA, A., RODRIGUEZ, L. Sustainable Development and Corporate Performance: A Study Based on the Dow Jones Sustainability Index. Journal of Business Ethics. 2007, Vol. 75, Iss. 3, pp. 282-300. ISSN 0167-4544.

[21] MAHONEY, L., ROBERTS, R. W. Corporate social performance, financial performance and institutional ownership in Canadian firms. Accounting Forum. 2007, Vol. 31, Iss. 3, pp. 233-253. ISSN 1467-6303.

[22] MCWILLIAMS, A., SIEGEL, D. Corporate social responsibility: A theory of the firm perspective. Academy of Management Review. 2001, Vol. 26, Iss. 1, pp. 117-127. ISSN 0363-7425.

[23] MURRAY, A., SINCLAIR, D., POWER, D., GRAY, R. Do financial markets care about social and environmental disclosure? Accounting, Auditing \& Accountability Journal. 2006, Vol. 19, Iss. 2, pp. 228-255. ISSN 0951-3574.

[24] O'DWYER, B., \& OWEN, D. L. Assurance statement practice in environmental, social and sustainability reporting: a critical evaluation. The British Accounting Review. 2005, Vol. 37, Iss. 2, pp. 205-229. ISSN 0890-8389.

[25] ORLITZKY, M. Does firm size confound the relationship between corporate social performance and firm financial performance? Journal of Business Ethics. 2001, Vol. 33, Iss. 2, pp. 167-180. ISSN 0167-4544.

[26] OWEN, D. L. Chronicles of wasted time?. A personal reflection on the current state of, and future prospects for, social and environmental accounting research. Accounting, Auditing \& Accountability Journal. 2008, Vol. 21, Iss. 2, pp. 240-267. ISSN 0951-3574.

[27] PAVA, M. L., KRAUSZ, J. The association between corporate social-responsibility and financial performance: the paradox of social cost. Journal of Business Ethics. 1996, Vol. 15, Iss. 3, pp. 321-357. ISSN 0167-4544.

[28] PRESTON, L. E., O'BANNON, D. P. The corporate social-financial performance relationship. Business and Society Review. 1997, Vol. 36, Iss. 4, pp. 419-429. ISSN 1467-8594.

[29] RUSSO, M. V., FOUTS, P. A. A ResourceBased Perspective on Corporate Environmental Performance and Profitability. The Academy of Management Journal. 1997, Vol. 40, Iss. 3, pp. 534-559. ISSN 0001-4273.

[30] STATACORP. Stata Statistical Software (Version 10). College Station (TX): StataCorp LP. 2007. ISBN 978-0-495-55786-9.
[31] TELLE, K. It Pays to be Green - A Premature Conclusion? Environmental and Resource Economics. 2006, Vol. 35, Iss. 3, pp. 195-220. ISSN 0924-6460.

[32] VAN DER LAAN, G., VAN EES, H., VAN WITTELOOSTUIJN, A. Corporate Social and Financial Performance: An Extended Stakeholder Theory, and Empirical Test with Accounting Measures. Journal of Business Ethics. 2008, Vol. 79, Iss. 3, pp. 299-310. ISSN 0167-4544.

[33] WADDOCK, S. A., GRAVES, S. B. The corporate social performance - financial performance link. Strategic Management Journal. 1997, Vol. 18, Iss. 4, pp. 303-319. ISSN 1097-0266.

[34] WAGNER, M., VAN PHU, N., AZOMAHOU, T., WEHRMEYER, W. The relationship between the environmental and economic performance of firms: an empirical analysis of the European paper industry. Corporate Social Responsibility and Environmental Management. 2002, Vol. 9, Iss. 3, pp. 133-146. ISSN 1535-3966.

[35] WHITE, H. A heteroskedasticity-consistent covariance matrix estimator and a direct test for heteroskedasticity. Econometrica. 1980, Vol. 48, Iss. 4, pp. 817-830. ISSN 0012-9682.

[36] WOOD, D. J. Corporate Social Performance Revisited. Academy of Management Review. 1991, Vol. 16, Iss. 4, pp. 691-718. ISSN 0363-7425. [37] WOOLDRIDGE, J. M. Econometric Analysis of Cross Section and Panel Data. Cambridge (MA): MIT Press, 2002. ISBN 978-0-262-23219-7. [38] ZIEGLER, A., SCHRÖDER, M., RENNINGS, K. The effect of environmental and social performance on the stock performance of European corporations. Environmental and Resource Economics. 2007, Vol. 37, Iss. 4, pp. 661-680. ISSN 0924-6460.

Voicu D. Dragomir, PhD. Academy of Economic Studies of Bucharest Faculty of Accounting and Management Information Systems Department of International Accounting and Financial Reporting voicudragomir@gmail.com

Doručeno redakci: 10. 8. 2010

Recenzováno: 20. 9. 2010, 10. 11. 2010

Schváleno k publikování: 17. 1. 2013 


\section{ENVIRONMENTAL PERFORMANCE AND RESPONSIBLE CORPORATE GOVERNANCE: AN EMPIRICAL NOTE}

\section{Voicu D. Dragomir}

Does it pay to be green? This question is by no means new or surprising; but what is really puzzling is that dedicated research efforts have failed to provide consistent evidence on this issue. Therefore, the 'business case' for sustainability is controversial, despite the fact that companies are more and more under pressure to standardize and expand their voluntary ethical practices. The research design serves the purpose of answering some of these questions: 77 large industrial European companies were included in a highly-relevant new dataset, containing aggregated greenhouse gas emission figures, as well as universally-accepted financial performance indicators. On these balanced panel data we conducted several types of analyses, tailored to capture the sign and strength of the relationship between environmental and financial performance. We also introduced an innovative measure of responsible governance, as an interaction term between board-level innovations and the level of independent assurance. Our results are mixed, largely dependent on different model specifications and the several procedures to obtain robust standard errors. As expected, there is no definitive conclusion on the aforementioned relationship. Responsible governance seems to have an insignificant contribution to real sustainability performance, as well as to the economic welfare of the firm. Overall, we support the results to be found in the prior literature, in that CSR attributes - here including emission reduction efforts - will bear higher costs, but also higher revenues, resulting in a neutral relationship between CSR activity and firm financial performance. Owing to the uniqueness of the database in use and to the complexity of the econometric analysis, our findings are another proof of the controversy surrounding the relationship between firm financial and environmental performance.

Key Words: Greenhouse gas emissions, European Union, financial performance, sustainability, environmental performance, corporate governance, corporate social responsibility.

JEL Classification: G3, L25, M4, Q5. 